\title{
In Vivo Effect of Indomethacin to Potentiate the Renal Medullary Cyclic AMP Response to Vasopressin
}

\author{
Gary M. Lum, Gary A. Aisenbrey, Michael J. Dunn, Tomas Berl, \\ ROBERT W. SCHRIER, and KeITH M. MCDONALD \\ From the Division of Renal Diseases, Departments of Medicine and Pediatrics, University of Colorado \\ Medical School, Denver, Colorado 80220 and the Nephrology Unit, Department of Medicine, \\ University of Vermont, Burlington, Vermont 05401
}

A B S T RA C T In a previous study we demonstrated that indomethacin potentiated the hydro-osmotic action of vasopressin in vivo. It was hypothesized that this action of indomethacin was due to its ability to suppress renal medullary prostaglandin synthesis, since in vitro studies have suggested that prostaglandins interfere with the ability of vasopressin to stimulate production of its intracellular mediator, cylcic AMP. In the present study this hypothesis was tested in vivo. Anesthetized rats undergoing a water diuresis were studied. In a control group, bolus injections of $200 \mu \mathrm{U}$ of vasopressin caused a rise in urinary osmolality (Uosm) from $124 \pm 6$ to $253 \pm 20 \mathrm{mosmol} /$ $\mathrm{kg} \mathrm{H}_{2} \mathrm{O}(P<0.005)$. In a group treated with $2 \mathrm{mg} / \mathrm{kg}$ of indomethacin the same dose of vasopressin caused a significantly greater $(P<0.001)$ rise in Uosm from $124 \pm 7$ to $428 \pm 19 \mathrm{mosmol} / \mathrm{kg} \mathrm{H}_{2} \mathrm{O}$. Medullary tissue cyclic AMP rose from 9.4 \pm 0.9 to $13.4 \pm 1.7(P<0.05) \mathrm{pmol} / \mathrm{mg}$ tissue protein after vasopressin administration in animals receiving no indomethacin, while in indomethacin-treated animals there was a significantly greater rise $(P$ $<0.001$ ) in medullary cyclic AMP from $10.4 \pm 0.9$ to $21.6 \pm 2.1 \mathrm{pmol} / \mathrm{mg}$ tissue protein in response to the vasopressin injections. In neither control animals nor indomethacin-treated animals were there significant changes in renal hemodynamics, as measured by clearance techniques. Indomethacin, when given alone, had no effect on Uosm or medullary tissue cyclic AMP. Indomethacin did, however, reduce medullary prostaglandin $\mathrm{E}$ content from $84.7 \pm 15.0$ to $15.6 \pm 4.3 \mathrm{pg} / \mathrm{mg}$ tissue. This study has shown that indomethacin, in a dose which suppresses medullary prostaglandin content, potentiates the ability of vasopressin to increase the tissue con-

Received for publication 8 July 1975 and in revised form 9 July 1976. tent of its intracellular mediator, cyclic AMP. Indomethacin caused no demonstrable inhibition of cyclic AMP phosphodiesterase. Therefore, it seems likely that indomethacin enhanced the ability of vasopressin to increase medullary cyclic AMP levels by causing an increased production rather than decreased destruction of the nucleotide. We conclude that this action of indomethacin contributes to its ability to potentiate the hydro-osmotic action of vasopressin in vivo. A corollary to this conclusion is that endogenous medullary prostaglandin E's may be significant physiological modulators of the renal response to vasopressin.

\section{INTRODUCTION}

Indications have arisen from in vitro studies that prostaglandin $\mathrm{E}_{1}\left(\mathrm{PGE}_{1}\right)^{1}$ blunts the ability of vasopressin to increase water permeability of the distal nephron $(1,2)$. Experiments in our laboratory have recently shown that drugs that inhibit prostaglandin synthesis potentiate the in vivo hydro-osmotic action of vasopressin in the anesthetized $\operatorname{dog}(3)$. This finding supports the concept that renal prostaglandins modulate tubular responsiveness to vasopressin. One of the mechanisms by which they might do so is suggested by the experiments of Beck et al. with rat medullary tissue slices (2). This in vitro study showed that PGE $_{1}$ impaired the ability of vasopressin to stimulate production of its intracellular mediator, $3^{\prime}, 5^{\prime}$-cyclic AMP (cyclic AMP). If this finding is relevant to in vivo conditions, then renal medullary prostaglandins would be expected to impair the stimulation of medullary cyclic AMP production by

\footnotetext{
${ }^{1}$ Abbreviations used in this paper: cyclic AMP, 3'5'cyclic AMP; PAH, para-aminohippurate; PDE, phosphodiesterase; $\mathrm{PGE}$, prostaglandin $\mathrm{E} ; \mathrm{PGE}_{1}$, prostaglandin $\mathrm{E}_{1}$; Uosm, urinary osmolality.
} 
vasopressin. It follows that drugs that block prostaglandin synthesis should enhance the medullary cyclic AMP response to vasopressin.

The present study was performed in intact rats to examine this possibility.

\section{METHODS}

Sprague-Dawley rats of either sex weighing $200-250 \mathrm{~g}$ were anesthetized with intraperitoneal Inactin (Promonta, Hamburg, W. Germany) Polyethylene cannulas were inserted into a jugular vein and femoral artery for the purpose of infusions and measurement of arterial blood pressure, respectively. The bladder was catheterized through a suprapubic incision, with care taken to ligate the bladder to eliminate dead space. A water diuresis was induced by infusing $0.45 \%$ saline at a constant rate of $12 \mathrm{ml} / \mathrm{h}$ until a urinary osmolality (Uosm) had been achieved and stablized below $150 \mathrm{mosmol} / \mathrm{kg} \mathrm{H}_{2} \mathrm{O}$. The average duration of the $0.45 \%$ saline infusion required to induce this stable diuresis was $2 \mathrm{~h}$.

The animals were then studied under one of four experimental protocols. Six animals were studied in each protocol.

Control group. These animals received only $0.45 \%$ saline throughout the experiment. When a stable diuresis, as determined by urine flow and Uosm, had been maintained for at least $30 \mathrm{~min}$, the kidneys were exposed through a midline abdominal incision, quickly removed, sliced on the sagittal plane, and frozen in liquid nitrogen. The total elapsed time between removal of the kidneys and freezing ranged between 10 and $15 \mathrm{~s}$. While the tissue was still frozen, the medulla and papillae were dissected out together. The tissue of each kidney was handled separately, transferred into $1.5 \mathrm{ml}$ of $10 \% \mathrm{TCA}$ and homogenized. The homogenates were centrifuged at $12,000 \mathrm{rpm}$ for 30 min in a refrigerated centrifuge. The supernates were decanted and the pellet was saved for determination of protein content by means of the biuret method (4). The supernate of each specimen was then extracted five times with $5 \mathrm{vol}$ of ether. Tracer quantities of $\left[{ }^{3} \mathrm{H}\right]$ cyclic AMP were added to each supernate to allow estimation of recovery of cyclic AMP in the subsequent assay. This aqueous phase was then passed over a 4-cm Dowex 50 AGW $\times 8,200-400$ mesh resin (Bio-Rad Laboratories, Richmond, Calif.). The eluate was lyophilized and the residue was redissolved in $200 \mu \mathrm{l}$ of $50 \mathrm{mM}$ sodium acetate. A $100-\mu \mathrm{l}$ aliquot was saved for determination of tritium content. Based on this measurement, recovery of cyclic AMP was found to range between 60 and $70 \%$. Duplicate $50-\mu \mathrm{l}$ aliquots of each specimen were then assayed for cyclic AMP by the method of Gilman (5). The cyclic AMP content of the medulla of each kidney was expressed as picomoles of cyclic AMP per milligram of protein.

Indomethacin group. This group of rats was subjected to the same experimental maneuvers as the Control group, except that after a stable water diuresis had been established for at least $30 \mathrm{~min}$ the animals were given $2.0 \mathrm{mg} / \mathrm{kg}$ of indomethacin by slow, intravenous injection over a period of $5 \mathrm{~min}$. The drug was prepared for injection by dissolving it in a $1.14 \mathrm{mg} / 100 \mathrm{ml}$ sodium carbonate buffer, $\mathrm{pH} 8.5$, at a concentration of $3.57 \mathrm{mg} / \mathrm{ml}$. The $0.45 \%$ saline infusion was continued for $30 \mathrm{~min}$ after the dose of indomethacin during which time the urine flow and Uosm were measured and remained constant at the levels which existed before the indomethacin injection. The kidneys were then rapidly removed, snap frozen, and
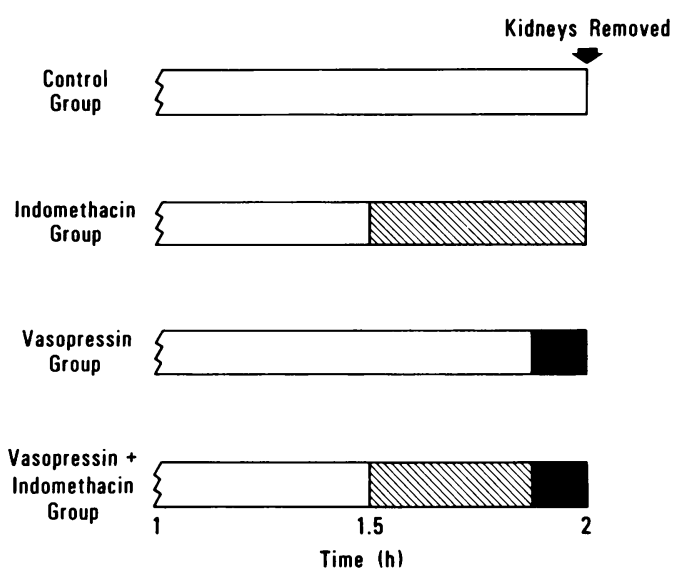

Figure 1 Experimental design. Schema for four protocols used in water-diuresing rats. In all four groups the kidneys were removed at the same time. In the Control group no drugs were given; in the Indomethacin group IV, indomethacin $(2 \mathrm{mg} / \mathrm{kg}$ ) was administered $1 \mathrm{~h}$ before removal of kidneys; in the Vasopressin group, vasopressin $(200 \mu \mathrm{U})$ was given 30 min before removal of kidneys; and in the Indomethacin and vasopressin group the two drugs were administered $1 \mathrm{~h}$ and $30 \mathrm{~min}$, respectively, before removal of kidneys.

the medullas excised for cyclic AMP analysis as described for the Control group.

Vasopressin group. This group of animals also underwent the same experimental maneuvers as the Control group, except that after $30 \mathrm{~min}$ of stable water diuresis they were given an intravenous bolus injection of $200 \mu \mathrm{U}$ of vasopressin (Aqueous Pitressin, Parke, Davis \& Co., Detroit, Mich.). The vasopressin used throughout the study was obtained from a single batch. $7-10 \mathrm{~min}$ after the vasopressin injection, at a time when the antidiuresis was approaching its peak, the kidneys were removed and the medullas were analyzed for cyclic AMP content as previously described.

Indomethacin plus vasopressin group. The animals in this group were given a constant infusion of $0.45 \%$ saline throughout the study as described for the previous three groups. After $30 \mathrm{~min}$ of stable water diuresis, $2.0 \mathrm{mg} / \mathrm{kg}$ of indomethacin was given intravenously as in the Indomethacin group. After an additional $30 \mathrm{~min}$ of recorded, stable water diuresis, the animals were given $200 \mu \mathrm{U}$ of vasopressin intravenously. $10 \mathrm{~min}$ after the vasopressin injection the kidneys were removed and the medullas analyzed for cyclic AMP as described previously. In six additional animals treated in this manner, clearance measurements of inulin and para-aminohippurate (PAH) were carried out for the purpose of estimating glomerular filtration rate and effective renal plasma flow, respectively. The protocols for the above four groups are summarized in Fig. 1.

Finally, renal medullary tissues from six rats in the Control group, the Indomethacin group, the Vasopressin group, and the Indomethacin plus vasopressin group were assayed for phosphodiesterase (PDE) activity according to the method of Thompson and Appleman and Brooker et al. $(6,7)$. A similar set of experiments was performed on six waterdiuresing rats given $50 \mathrm{mg} / \mathrm{kg}$ aminophylline intravenously instead of indomethacin. The purpose of this protocol was to determine whether the well-known inhibitor of PDE, aminophylline, when given in vivo, could be shown to 

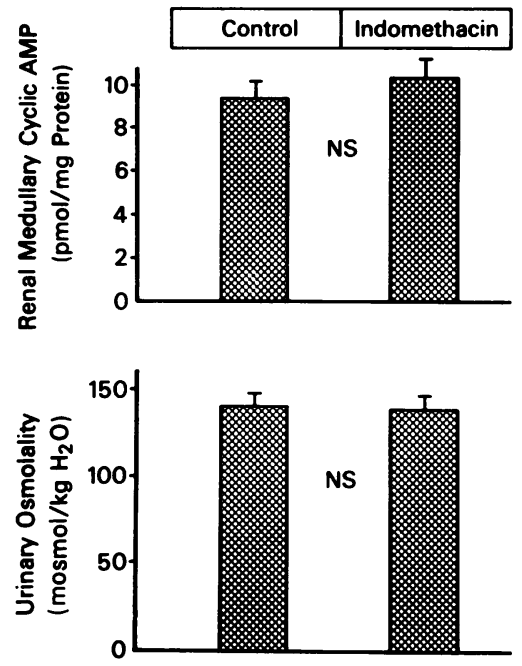

FIGURE 2 Effect of indomethacin on renal medullary cyclic AMP and Uosm. Cyclic AMP data were obtained from 12 separately analyzed kidneys from six rats in the Control group and the Indomethacin group. NS refers to lack of statistical significance as evidenced by $P<0.05$.

suppress the enzyme activity in the renal medulla under the conditions of our experiments. The kidneys were removed, bisected sagitally and the medullas dissected. The medullary tissues were weighed and homogenized in $0.3 \mathrm{ml}$ water per $100 \mathrm{mg}$ of tissue. The homogenates were centrifuged and the supernates retained for analysis of PDE activity. $20 \mu$ l of the supernates was added to liquid scintillation vials containing a freshly prepared mixture of $350 \mu \mathrm{l}$ of $50-\mathrm{mM}$ Tris buffer ( $\mathrm{pH} 8.0$ ); $20 \mu \mathrm{l}$ of $0.1-\mathrm{m} \mathrm{MgCl}_{2}$; $15 \mu \mathrm{l}$ of $0.05-\mathrm{pM}\left[{ }^{3} \mathrm{H}\right]$ cyclic AMP (Schwarz Mann Div., Becton, Dickinson \& Co., Orangeburg, N.Y., sp act $23 \mathrm{Ci} / \mathrm{mM}$ ); and $20 \mu \mathrm{l}$ of $200-\mathrm{pM}$ unlabeled cyclic AMP for a final assay volume of $425 \mu \mathrm{l}$. This mixture was then incubated at $30^{\circ} \mathrm{C}$ for $10 \mathrm{~min}$. The reaction was stopped by $3 \mathrm{~min}$ of boiling. The vials were transferred to an ice bath and $0.1 \mathrm{U}$ of $5^{\prime}$ nucleotidase in the form of Crotalus adenanteus venom was added. The vials were then incubated at $30^{\circ} \mathrm{C}$ for $15 \mathrm{~min}$. At the end of this period, $1 \times 8-400$ Dowex resin, together with $15 \mathrm{ml}$ of scintillation fluid was added to each sample and after vortexing and centrifugation the vials were placed in an LS-150 Beckman liquid scintillation counter (Beckman Instruments, Inc., Fullerton, Calif.) for the measurement of tritium activity. This activity was assumed to arise from the $\left[{ }^{3} \mathrm{H}\right]$ adenosine in the supernate. In parallel with these unknowns, a set of standards and blanks was carried through the same procedures. Standards contained no tissues, and blanks likewise contained no tissue and also no Dowex resin. The PDE activity in the medullary tissue extract is estimated by comparing the activity in the unknown tubes with that in the standard. The protein content of the tissue extracts was measured by the biuret method and PDE activity expressed as nanomoles of cyclic AMP converted to $5^{\prime}$ AMP per $10 \mathrm{~min} / \mathrm{mg}$ of protein.

Studies were also performed to determine whether the dose of $2.0 \mathrm{mg} / \mathrm{kg}$ of indomethacin used in our experiments suppressed medullary prostaglandin content. Measurements of prostaglandin E (PGE) were carried out on pooled medullary tissue extracts obtained from rats in the Control group and the Indomethacin group. These measurements were performed both at the University of Vermont and at the University of Colorado with a modified version of the radioimmunoassay of Levine et al. (8).

Comparisons of data from the different groups of animals were evaluated by means of analysis of variance (9).

\section{RESULTS}

Control group. These animals received only $0.45 \%$ saline and served as the reference group for the following experimental groups. The mean Uosm of the control group was $130 \pm 13 \mathrm{mosmol} / \mathrm{kg} \mathrm{H}_{2} \mathrm{O}$ and renal medullary tissue cyclic AMP content was $9.42 \pm 0.89$ $\mathrm{pmol} / \mathrm{mg}$ protein.

Indomethacin group. The mean Uosm during the control period in this group stabilized at $140 \pm 6$ mosmol/kg $\mathrm{H}_{2} \mathrm{O}$. This value was not significantly different from the Uosm of the Control group noted above. After the intravenous infusion of $2 \mathrm{mg} / \mathrm{kg}$ of indomethacin the mean Uosm remained unchanged at $139 \pm 8 \mathrm{mosmol} / \mathrm{kg} \mathrm{H}_{2} \mathrm{O}$. Medullary tissue cyclic AMP and Uosm in these animals receiving indomethacin are compared with the Control group in Fig. 2. It is apparent that the drug had no significant effect on either urine concentration or medullary cyclic AMP content.

Direct PGE measurements of medullary tissue showed a value of $15.6 \pm 4.3 \mathrm{pg} / \mathrm{mg}$ of tissue in the Indomethacin group compared to $84.7 \pm 15.0 \mathrm{pg} / \mathrm{mg}$ of tissue in the Control group. The medullas from both kidneys of each rat were pooled for each measurement. 8 pairs of kidneys were studied in the Control group and 10 pairs in the Indomethacin group.

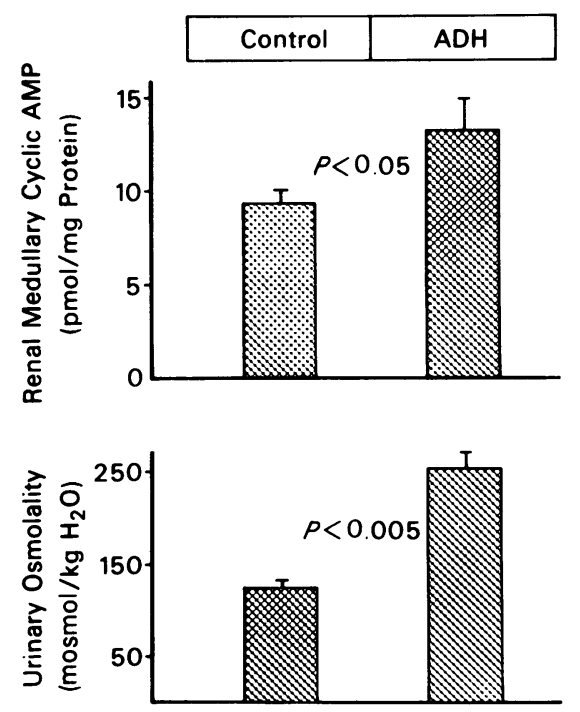

Figure 3 Effect of vasopressin on renal medullary cyclic AMP and Uosm. Cyclic AMP data obtained from 12 separately analyzed kidneys from six rats in both the Control group and the Vasopressin group. 
The statistical analysis was by unpaired Student's $t$ test. The difference between the two groups was highly significant $(P<0.001)$. The results obtained at the University of Vermont and the University of Colorado were within the same range so the data were pooled for the statistical analysis.

Vasopressin group. The mean Uosm during the control period in this group was $124 \pm 6 \mathrm{mosmol} / \mathrm{kg}$ $\mathrm{H}_{2} \mathrm{O}$, a value not significantly different from that of the Control group. Uosm then rose to $253 \pm 20 \mathrm{mosmol} /$ $\mathrm{kg} \mathrm{H}_{2} \mathrm{O}(P<0.005)$ when a bolus of $200 \mu \mathrm{U}$ of vasopressin was given. The Uosm and medullary tissue cyclic AMP content of the Vasopressin group are compared with the Control group in Fig. 3. Both parameters increased significantly in response to vasopressin administration.

Indomethacin plus vasopressin group. The Uosm during the control period in this group was $124 \pm 7$ $\mathrm{mosmol} / \mathrm{kg} \mathrm{H}_{2} \mathrm{O}$ and remained unchanged at $124 \pm 6$ $\mathrm{mosmol} / \mathrm{kg} \mathrm{H}_{2} \mathrm{O}$ after the administration of $2 \mathrm{mg} / \mathrm{kg}$ of indomethacin. However, when these animals were then given a bolus injection of $200 \mu \mathrm{U}$ of vasopressin, the Uosm rose to $428 \pm 19 \mathrm{mosmol} / \mathrm{kg}$ $\mathrm{H}_{2} \mathrm{O}$, a value significantly greater $(P<0.01)$ than that achieved in the previous group receiving this dose of vasopressin in the absence of indomethacin. Similarly, medullary tissue content of cyclic AMP was significantly greater in the animals receiving vasopressin superimposed on indomethacin than in those receiv-

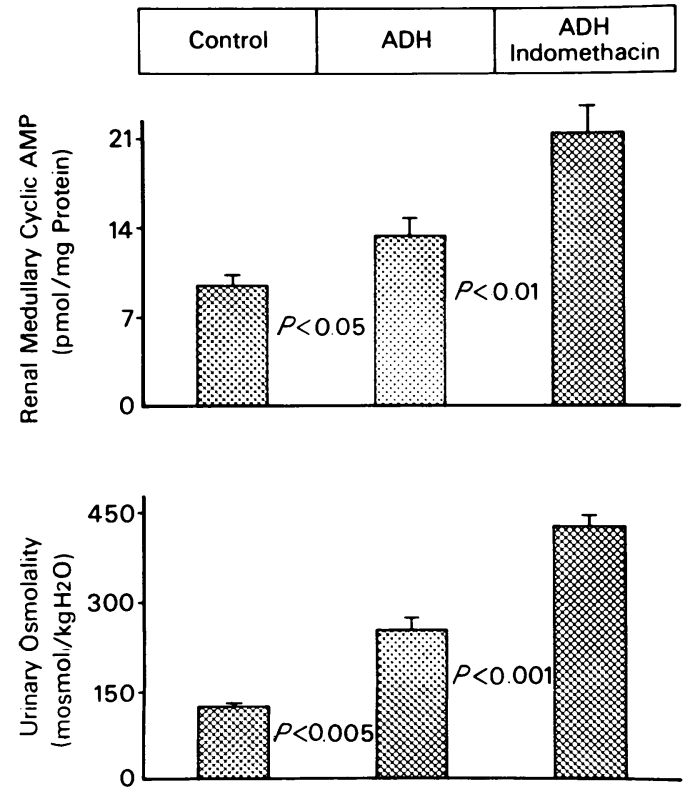

FIGURE 4 Comparison of medullary cyclic AMP values and Uosm in animals from Control group, Vasopressin group, and Indomethacin plus vasopressin group. Cyclic AMP were determinations done on 12 kidneys obtained from six rats in each group.

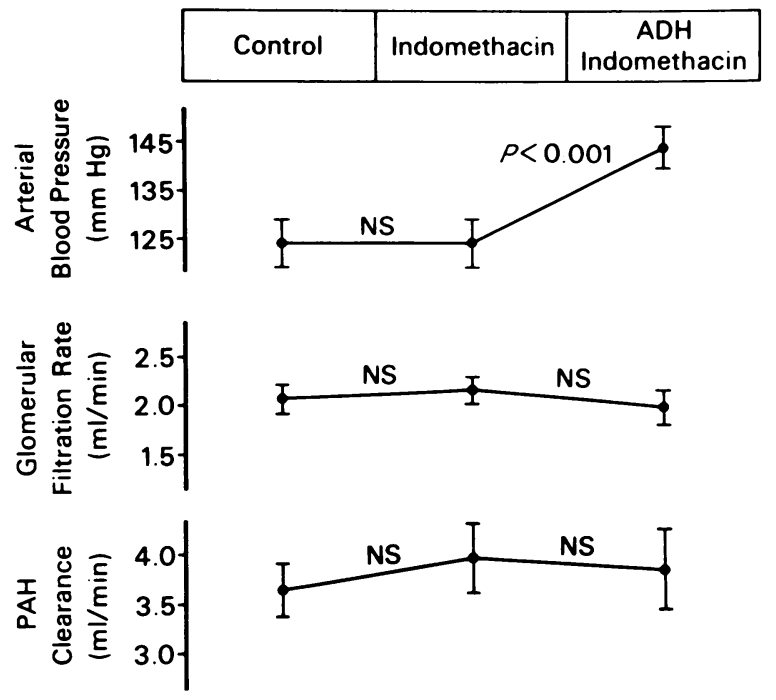

Figure 5 Arterial blood pressure, glomerular filtration rate, and renal blood flow in six water diuresing rats treated with indomethacin and vasopressin.

ing vasopressin alone $(21.6$ vs. $13.4 \mathrm{pmol} / \mathrm{mg}$ tissue protein, $P<0.01$ ).

Uosm and medullary tissue cyclic AMP values for the Control group, the Vasopressin group, and the Indomethacin plus vasopressin group are compared in Fig. 4. This demonstrates the potentiating effect of indomethacin on the hydro-osmotic and medullary cyclic AMP responses to vasopressin.

Fig. 5 summarizes the glomerular filtration rate, $\mathrm{PAH}$ clearance, and arterial blood pressure data. Indomethacin, alone, had no demonstrable effect on any of these parameters. Vasopressin, when given together with indomethacin, caused a significant rise in arterial pressure, but did not affect glomerular filtration rate or $\mathrm{PAH}$ clearance.

Table I compares the medullary PDE activity of control rats with that of rats in the Indomethacin group, the Vasopressin group, and the Vasopressin plus indomethacin group as well as the group treated with aminophylline. Neither indomethacin nor vasopressin nor indomethacin plus vasopressin had any demonstrable effect on PDE activity, while aminophylline suppressed it to about one-third of the control value.

\section{DISCUSSION}

A great deal of evidence indicates that cyclic AMP mediates the action of antidiuretic hormone on renal tubules and other epithelial membranes (10-13). In vitro studies have shown that $\mathrm{PGE}_{1}$ impairs the ability of vasopressin to stimulate cyclic AMP production (2). Because of this latter phenomenon, studies have been undertaken in our laboratory to determine 
TABLE I

Medullary Tissue PDE Activity* (Mean \pm SEM) in Control Rats and Rats Treated with Vasopressin, Indomethacin, Vasopressin Plus Indomethacin, or Aminophylline

\begin{tabular}{|c|c|c|c|c|}
\hline $\begin{array}{c}\text { Vasopressin } \\
\quad(n=6)\end{array}$ & $\begin{array}{c}\text { Indo- } \\
\text { methacin } \\
(n=6)\end{array}$ & $\begin{array}{l}\text { Indo- } \\
\text { methacin } \\
\text { plus } \\
\text { vasopressin } \\
(n=6)\end{array}$ & $\begin{array}{l}\text { Control } \\
(n=6)\end{array}$ & $\begin{array}{l}\text { Amino- } \\
\text { phylline } \\
(n=6)\end{array}$ \\
\hline $118.2 \pm 2.9$ & $113.4 \pm 5.8$ & $119.8 \pm 2.2$ & $114.9 \pm 4.7$ & $42.7 \pm 4.6$ \\
\hline
\end{tabular}

* Nanomolars of cyclic AMP converted to 5' AMP per milligram of protein per 10 minutes.

the physiological significance of the interaction between vasopressin and endogenous renal prostaglandins. That such an interaction may be important is suggested not only by the findings of in vitro experiments, but by the fact that the renal medulla and papilla, the primary sites of action of vasopressin, are also sites of abundant prostaglandin synthesis (14).

In an initial series of experiments performed on anesthetized dogs, we demonstrated that inhibitors of prostaglandin synthesis, namely indomethacin and sodium meclofenamate, greatly potentiate the in vivo hydroosmotic action of vasopressin (3). The present study was undertaken to investigate further the mechanism involved in this effect. One possible mechanism is that inhibition of prostaglandin synthesis causes a decrease in medullary blood flow $(15,16)$ which then enhances the hypertonicity of the medullary interstitium. This increased osmotic gradient would facilitate the osmotic movement of water across the collecting ducts into the interstitium and thereby enhance the ability of vasopressin to promote urine concentration. If such a purely hemodynamic mechanism accounted for the potentiation of vasopressin activity in vivo by prostaglandin inhibition, the cellular interactions of prostaglandins with vasopressin which have been demonstrated in vitro $(2,15,17)$ would be of doubtful in vivo physiological significance. Against this hemodynamic mechanism, however, is the recent finding that indomethacin enhances the in vivo action of vasopressin in the conscious rat, a setting in which the drug has not been found to alter renal hemodynamics (18).

The present study was undertaken in the rat to examine whether inhibition of prostaglandin synthesis with indomethacin $(19,20)$ enhances the in vivo effect of vasopressin to increase simultaneously Uosm and medullary concentration of cyclic AMP. Such an in vivo finding would provide strong evidence that prostaglandin inhibition acts by enhancing the cellular effect of vasopressin.

The present results did demonstrate that pretreat- ment of water diuresing rats with indomethacin resulted in both a significantly greater rise in Uosm and medullary cyclic AMP concentration. As expected from previous studies $(19,20)$, these effects of indomethacin were associated with a profound fall in the medullary concentration of prostaglandins. This effect of indomethacin to suppress medullary prostaglandin, as vasopressin-induced increases in Uosm and cyclic AMP were enhanced, is compatible with the hypothesis of Grantham and Orloff (1) that endogenous prostaglandins impair the cellular action of vasopressin to stimulate cyclic AMP production.

An alternative explanation, however, was also examined in the present study. The enhanced cyclic AMP response to vasopressin after indomethacin treatment may have been due to an effect of the drug to inhibit the degradation of cyclic AMP, rather than to enhance its production. This possibility was tenable since large doses of indomethacin administered in vitro have been found to inhibit PDE, the degradative enzyme of cyclic AMP (21, 22). Against this interpretation, however, was the observation in the present study that the administration of indomethacin alone did not increase the medullary concentration of cyclic AMP. This finding could be interpreted to exclude an effect of indomethacin to decrease medullary PDE activity, since, if this were the case, indomethacin alone might have been expected to increase medullary cyclic AMP concentrations. Such an interpretation is, however, not totally justifiable since other inhibitors of cyclic AMP PDE, such as aminophylline, may increase cyclic AMP only in the vasopressin-stimulated state. Thus, it was necessary to determine directly the effect of indomethacin on medullary tissue PDE activity. With the dose of indomethacin which enhanced the hydro-osmotic and cyclic AMP generating effects of vasopressin, the medullary tissue PDE levels were found not to be different in the nontreated control and indomethacin-treated groups of rats. This was true whether the indomethacin was given during a water diuresis, when medullary cyclic AMP was suppressed, or during administration of vasopressin when cyclic AMP production was stimulated. The possibility remains, and cannot be refuted conclusively by our experiments, that the results of our PDE assays do not reflect the activity of the enzyme in vivo. In preparation for the assay, the tissue extracts were diluted by a factor of 1:40. This dilution would be expected to alter the enzyme activity quantitatively. However, it is important to note that the dilution affected all constituents of the tissue equally. Thus, the enzyme, its endogenous substrate (cyclic AMP) and the indomethacin in the tissue extract were all diluted by a factor of $1: 40$ so that their relative concentrations in the assay system would be 
comparable to those existing in vivo. Moreover, the same dilution of the tissue extract was used in all groups of animals studied. Therefore, it seems unlikely that the assay procedure would have introduced a systematic change in the enzyme kinetics which would have obscured an inhibitory effect of indomethacin on PDE. This argument is supported by the fact that aminophylline, when given in vivo, was shown by means of the same assay to cause a marked suppression of PDE activity. While this latter observation is not proof that indomethacin had no inhibitory effect on PDE in our experiments, it does show that the assay is capable of detecting enzyme inhibition after a PDE inhibiting drug is administered in vivo.

On the basis of the present study, therefore, the conclusion seems justifiable that indomethacin potentiates the in vivo hydro-osmotic effects of vasopressin by potentiating the ability of the hormone to stimulate cyclic AMP production. This action of indomethacin was associated with a suppression of medullary PGE content, but with no demonstrable suppression of cyclic AMP PDE activity. Thus, suppression of endogenous medullary PGE seems to constitute a pathway whereby indomethacin potentiates the in vivo action of vasopressin. A possible extension of this conclusion is that endogenous renomedullary prostaglandins may be physiological and pathophysiological modulators of the hydroosmotic action of vasopressin.

\section{ACKNOWLEDGMENTS}

We would like to thank Mr. David Hyde for his assistance in developing the cyclic AMP assay and Ms. Linda M. Benson for typing the manuscript.

This study was supported by grant HL 15629 from the National Institutes of Health.

\section{REFERENCES}

1. Grantham, J. J., and J. Orloff. 1968. Effect of prostaglandin $E_{1}$ on the permeability response of the isolated collecting tubule to vasopressin, adenosine $3^{\prime}, 5^{\prime}$ monophosphate and theophylline. J. Clin. Invest. 47: 1154-1161.

2. Beck, N. P., T. Kaneko, U. Zor, J. B. Field, and B. B. Davis. 1971. Effects of vaospressin and prostaglandin $E_{1}$ on the adenyl cyclase-cyclic $3^{\prime}, 5^{\prime}$-adenosine monophosphate system of the renal medulla of the rat.J. Clin. Invest. 50: 2461-2465.

3. Anderson, R. J., T. Berl, K. M. McDonald, and R. W. Schrier. 1975. Demonstration of in vivo antagonism between vasopressin and prostaglandin in the mammlian kidney. J. Clin. Invest. 56: 420-426.

4. Layne, E. 1957. Spectrophotometric and turbimetric methods for measuring proteins. Methods Enzymol. 3: 447-454.

5. Gilman, A. G. 1972. Protein binding assays for cyclic nucleotides. Adv. Cyclic Neucleotide Res. 2: 9-24.

6. Thompson, J. W., and M. M. Appleman. 1971. Multiple cylcic nucleotide phosphodiesterase activity from rat brain. Biochemistry 10: 311-316.

7. Brooker, G., L. J. Thomas, Jr., and M. M. Appleman. 1968. The assay of adenosine $3^{\prime}-5^{\prime}$ cyclic monophosphate and guanosine $3^{\prime}-5^{\prime}$ cyclic monophosphate in biological material by enzymatic radioisotopic displacement. Biochemistry. 7: 4177-4181.

8. Levine, L., R. M. Gutierrez Cironosek, and H. Van Vunakis. 1971. Specificities of prostaglandins $B_{1}, F_{1 \alpha}$ and $F_{2 \alpha}$ antigen-antibody reactions. J. Biol. Chem. 246: 6782-6785.

9. Remington, R. D., and M. A. Schork. 1970. Statistics with Applications to the Biological and Health Sciences. Prentice-Hall, Inc., Englewood Cliffs, N. J. 282.

10. Orloff, J., and J. S. Handler. 1962. The similarity of effects of vasopressin, adenosine $3^{\prime}, 5^{\prime}$-phosphate (cyclic AMP) and theophylline on the toad bladder. J. Clin. Invest. 41: 702-709.

11. Handler, J. S., R. W. Butcher, E. W. Sutherland, and J. Orloff. 1965. The effect of vasopressin and of theophylline on the concentration of adenosine $3^{\prime}, 5^{\prime}$-phosphate in the urinary bladder of the toad. J. Biol. Chem. 240: 4524-4526.

12. Chase, L. R., and G. D. Aurbach. 1968. Renal adenyl cyclase: Anatomically separate sites for parathyroid hormone and vasopressin. Science (Wash., D. C.). 159: 545-547.

13. Dousa, T. P. 1973. The role of cyclic AMP in the action of antidiuretic hormone on kidney. Life Sci. 13: $1033-1040$.

14. Hinman, J. W. 1972. Prostaglandins. Annu. Rev. Biochem. 41: 161-178.

15. Itskovitz, H. D., J. Stemper, D. Pacholczyk, and J. C. McGiff. 1973. Renal prostaglandins: Determinants of intrarenal distribution of blood flow in the dog. Clin. Sci. Mol. Med. 45 (Suppl. I): 321s-324s.

16. Kirschenbaum, M. A., N. White, J. H. Stein, and T. F. Ferris. 1974. Redistribution of renal cortical blood flow during inhibition of prostaglandin synthesis. Am. J. Physiol. 227: 801-805.

17. Lipson, L. C., and G. W. G. Sharp. 1971. Effect of prostaglandin $E_{1}$ on sodium transport and osmotic water flow in the toad bladder. Am. J. Physiol. 220: 1046-1052.

18. Berl, T., W. Czaczkes, and C. Kleeman. 1975. Effect of prostaglandin synthesis inhibition on the renal action of vasopressin. Studies in man and the rat. Proc. Am. Soc. Nephrol. 72.

19. Vane, J. R. 1971. Inhibition of prostaglandin synthesis as a mechanism of action for aspirin-like drugs. Nat. New Biol. 231: 232-235.

20. Flower, R. J. 1974. Drugs which inhibit prostaglandin biosynthesis. Pharmacol. Rev. 26: 33-67.

21. Flores, A. G. A., and G. W. G. Sharp. 1972. Endogenous prostaglandins and osmotic water flow in the toad bladder. Am. J. Physiol. 223: 1392-1397.

22. Newcombe, D. S., N. M. Thanassi, and C. P. Ciosek, Jr. 1974. Cartilage cyclic nucleotide phosphodiesterase: Inhibition by anti-inflammatory agents. Life Sci. 14: 505-519. 